\title{
STUDY ON THE MAJOR DELAY FACTORS IN FINISHING WORKS BEFORE COMPLETION OF CONSTRUCTION
}

\author{
$\underline{\text { Min Seok Kim}}{ }^{1}$, Seung Kyu Yoo ${ }^{1}$, Ju Hyung Kim², and Jae Jun Kim²* \\ ${ }^{1}$ Department of Sustainable Architectural Engineering Hanyang University, Seoul, Korea \\ ${ }^{2}$ Department of Architectural Engineering, Hanyang University, Seoul, Korea \\ *Corresponding author (jjkim@hanyang.ac.kr)
}

\begin{abstract}
There are many variations and risks in construction work and the risk is getting increased in accordance of big scale, variation and complexity for the construction work. If the process management is not planned thoroughly, it affects the construction period. . The delay of construction period causes the increase of project budget and low productivity and it is the cause of poor construction for recovering the long-term suspension of construction in construction work. There are various problems such as low quality, negligent accidents, etc. Especially, the delay of finishing work can be fatal before the completion of construction. It is study on analysis of the influence factor for delay of construction period and how to apply in real work site in finishing work. It is regarded that this study will lead to thorough process movement in work site and critical data.
\end{abstract}

Keywords: Process Management, Delay of Construction Period, Finishing Work

\section{INTRODUCTION}

As the scale of construction is getting big, the rational process management is getting complicated and also it is important. The delay of construction period has been constantly occurred because of uncertain factors depending on the soil condition, site situation and correlated many types of construction (Daeup Lee, 2007)

The purpose of construction is to be economical and safe complication for quality specification specified on design book within construction period.

Finishing work means a series of subsequent work carried out after ground and structural construction in order to complete the final assessment of construction work also, it is relevant to various types of construction such as masonry construction, plaster work, doors and windows construction, waterproof construction, tile construction, interior finishing work, etc. (Youngjae KIM and others, 2003) Finishing work has various and complicated structures due to detailed process so, there are no standard for detailed construction type and necessity of setting up the priority between prior and post work are weak.
Superintendent should recognize the cause of delay for finishing work and set up the proper plan against the cause of delay of construction period between stages of structural work and finishing work.

This study is to analyze the cause of construction period for the frame work and finishing work and make the countermeasure for the delay of construction period in comparison of frame work.

\section{THEOLOGICAL BACKGROUND}

\subsection{Analysis of existing studies}

As considering the studies performed for above subjects, study on the method of analysis for the delay of construction period and estimate of delayed days for construction period and study on the calculation of damages according to the delay of construction period and the prevention of disputes have been performed. 
Table 1. Existing studies

\begin{tabular}{|c|c|}
\hline Title of study and writer & Contents \\
\hline Influence of the Structural & $\begin{array}{l}\text { Influence of the structural } \\
\text { framework on the work } \\
\text { period of critical path of } \\
\text { finish works }\end{array}$ \\
\hline $\begin{array}{l}\text { A Case Study on Reason } \\
\text { Analysis for Schedule } \\
\text { Delay of Apartment House, } \\
\text { Park, Chang-Wook (2009) }\end{array}$ & $\begin{array}{l}\text { Estimating the delayed days } \\
\text { of construction period and } \\
\text { analyzing the cause of delay } \\
\text { for the construction period } \\
\text { by Questionnaire survey for } \\
\text { relevant site in the } \\
\text { construction of apartment } \\
\text { house. }\end{array}$ \\
\hline $\begin{array}{l}\text { Delay Factors Based on } \\
\text { Importance of Finish Work } \\
\text { in Apartment Construction } \\
\text { Project, Lee, Seung-Hoon } \\
(2010)\end{array}$ & $\begin{array}{l}\text { Prioritizing the delay of } \\
\text { final works with importance } \\
\text { level of each types of } \\
\text { construction by dividing } \\
\text { finishing work into wet } \\
\text { construction and other } \\
\text { finishing works. }\end{array}$ \\
\hline $\begin{array}{l}\text { An Analysis on Delay } \\
\text { factors of Major Trades in } \\
\text { Apartment } \\
\text { Projects, Housing } \\
\text { Kwan(2003) }\end{array}$ & $\begin{array}{l}\text { Establishing the cause of } \\
\text { delay of construction period } \\
\text { from the point of view of } \\
\text { contractor and analyzing } \\
\text { the main cause of delay of } \\
\text { construction period on each } \\
\text { process and the status of } \\
\text { company in Korea }\end{array}$ \\
\hline
\end{tabular}

\subsection{CONSIDERATION OF THEORY FOR THE DELAY OF CONSTRUCTION PERIOD}

\subsubsection{Cause of the delay for construction period}

The Delay of construction period means the period when the part of whole project is extended or it's not executed due to unpredictable environment factors.(Callahan, 1992).

As for the analysis of delay for construction period, the related data is analyzed according to the cause of delay for the construction period and it is important stage to decide where the responsibility lies. Also, it is carried out by referring the contract and precedent, common practice, etc. So, the cause of delay for construction period should be analyzed precisely and tabl3 2.1 shows the cause of delay for construction period by each category. It is necessary to set the range for reviewing the related project document by finding relevant causes for each issue if there is claim of delay for construction period.

Table 2.1 Cause of delay for construction period

\begin{tabular}{|c|c|}
\hline Categories & Cause of delay \\
\hline Engineering & $\begin{array}{l}\text { Inaccurate drawings } \\
\text { Incomplete drawings } \\
\text { Late engineering }\end{array}$ \\
\hline Management & $\begin{array}{l}\text { Equipment breakdowns } \\
\text { Equipment delivery } \\
\text { Improper equipment } \\
\text { Shortage of equipment }\end{array}$ \\
\hline $\begin{array}{l}\text { E x t e r i o r } \\
\text { Delays }\end{array}$ & $\begin{array}{l}\text { Environmental issues } \\
\text { Later than planned start } \\
\text { Regular change } \\
\text { Permit approval }\end{array}$ \\
\hline Management & $\begin{array}{l}\text { Construction methods } \\
\text { More than planned } \\
\text { Quality assurance/quality control } \\
\text { Schedule too optimistic } \\
\text { Not working on critical tasks }\end{array}$ \\
\hline Labor & $\begin{array}{l}\text { Craft shortages } \\
\text { Labor productivity } \\
\text { Labor strike } \\
\text { Rework }\end{array}$ \\
\hline Materials & $\begin{array}{l}\text { Damaged goods } \\
\text { Improper tools } \\
\text { Material delivery } \\
\text { Material quality }\end{array}$ \\
\hline Weather & $\begin{array}{l}\text { Freezing } \\
\text { Heat and humidity } \\
\text { Rain } \\
\text { Snow }\end{array}$ \\
\hline
\end{tabular}




\section{ANALYSIS ON DELAY FACTOR FOR CONSTRUCTION PERIOD BY TYPES OF CONSTRUCTION}

\subsection{Factor of delay of frame work period}

The factor of frame work period is shown as below table 3.1. There are impossible factors to be managed by prior management because the most of frame work is carried out indoor so it is directly related to climatic condition and involves unpredictable negligent accidents or civil complaints, etc.

Table 3.1 Analysis on cause of delay for frame work period

\begin{tabular}{c|l}
\hline \multicolumn{1}{c}{$\begin{array}{c}\text { Type of } \\
\text { Construction }\end{array}$} & \multicolumn{1}{c}{ Cause } \\
\hline Frame Work & $\begin{array}{l}\text { Climatic condition } \\
\text { Shortage of labor plan } \\
\text { Poor or bankrupted subcontractor } \\
\text { Prevention and delay for civil complaint } \\
\text { Negligent accidents during construction } \\
\text { Improper construction and procedure } \\
\text { Suitability for method of construction } \\
\text { Error and omission for drawing } \\
\text { Shortage of labor experience }\end{array}$ \\
\hline
\end{tabular}

\subsection{Factor of delay for finishing work period}

The cause of delay for construction period is analyzed by dividing to 3 types of finishing work briefly. As table 3.2 shows the causes of delay of construction delay for each type of finishing work, it will be helpful to suggest the improvement of delay factor for construction period.

Table 3.2 Analysis of delay for construction period by each type of construction

\begin{tabular}{c|l}
\hline $\begin{array}{c}\text { Type of } \\
\text { Construction }\end{array}$ & \multicolumn{1}{|c}{ Cause } \\
\hline Masonry Work & $\begin{array}{l}\text { Shortage of labor plan } \\
\text { Plastering Work }\end{array}$ \\
Interference of other types of \\
construction \\
Wrong construction/plan for other
\end{tabular}

\begin{tabular}{|c|c|}
\hline & $\begin{array}{l}\text { types of construction } \\
\text { Wrong construction due to } \\
\text { discordance of drawing } \\
\text { Shortage of labor experience } \\
\end{array}$ \\
\hline $\begin{array}{l}\text { Doors and } \\
\text { windows } \\
\text { construction }\end{array}$ & $\begin{array}{l}\text { Shortage of labor plan } \\
\text { Poor or bankrupted subcontractor } \\
\text { Shortage of plan for establishment } \\
\text { fund }\end{array}$ \\
\hline $\begin{array}{c}\text { Interior finishing } \\
\text { construction }\end{array}$ & $\begin{array}{l}\text { Shortage of labor plan } \\
\text { Shortage of labor experience } \\
\text { Establishment fund } \\
\text { Shortage of plan }\end{array}$ \\
\hline
\end{tabular}

\section{CONCLUSION}

Personnel in project site regards as the delay of period of finishing work is less serious than Ground work or frame work but the delay of construction work before the completion of construction should be taken sensitively. Because the delay of construction work is directly related to the cost of construction from the point of view of the contractor.

This study analyzes the factors of delay of construction period for frame work and finishing work. It is understood that the frame work has different delay factors from the types of finishing work. It is the countermeasure of delay of construction period in finishing work.

1. Checking the drawing error by constant communication between designer, contractor and subcontractor

2. Making thorough plan, management and control for the initial finishing work

3. Making process plan and management to carry out the integrated management for frame work and finishing work

4. Setting up enough prior and post relations between types of finishing work

\section{ACKNOWLEDGMENT}

This research was supported by a grant (code No.06Chumdan-eunghapE01) from Virtualmighty Program by Ministry of Construction and Transportation of the Korean Government (MOEHRD)(R05-2004-000-10591-0) 


\section{REFERENCES}

[1] Daeup Lee, A Syudy on the Cause of Construction Delay and their Countermeasures, Sang-gi Uni. 2007

[2] Youngjae Kim and other 5 writers, “A Tact Planning and Scheduling Process Model for Reduction of Finishing Work Duration in Building Construction Projects", Journal of the Architectural Institute of Korea Structure and Construction, 19-1, pp. 161 168, 2003.

[3] Kim, Tae-Woo with 1 other writer, “Concurrent Delay Analysis Method: System Thinking Approach”, the Architectural Institute of Korea, Vol. 2(49), pp. 431, 2005.10

[4] Lee, Seung-Hoon, "Delay Factors Based on the Importance of Finish Work in Apartment Construction Project” Abstracts of Presentations at the Spring Meeting of the Architectural Institute of Korea, Vol. 10-1(18), pp. $125 \sim 129$

[5] ] Park, Chang-Wook, “A Case Study on Reason Analysis for Schedule Delay of Apartment House" Journal of The Korean Institute of Building Construction, Vol. 9-1, pp. $89 \sim 94,2009.02$

[6] Han, Jong-Kwan 외 2 명, “An Analysis on Delay factors of Major Trades in Apartment Housing Projects” Journal of the Architectural Institute of Korea, Vol. 193(173), pp. $163 \sim 170,2003.03$ 